\title{
The effect of phosphorus removal from sewage on the plankton community in a hypertrophic reservoir
}

Sungmin Jung ${ }^{1}$, Kiyong Kim², Yunkyoung Lee ${ }^{1}$, Jaeyong Lee', Yukyong Cheong ${ }^{1}$, Arif Reza', Jaiku Kim¹, Jeffrey S. Owen ${ }^{3}$ and Bomchul Kim ${ }^{1 *}$

\begin{abstract}
Background: When developing water quality improvement strategies for eutrophic lakes, questions may arise about the relative importance of point sources and nonpoint sources of phosphorus. For example, there is some skepticism regarding the effectiveness of partial reductions in phosphorus loading; because phosphorus concentrations are too high in hypertrophic lakes, in-lake phosphorus concentrations might still remain within typical range for eutrophic lakes even after the reduction of phosphorus loading. For this study, water quality and the phytoplankton and zooplankton communities were monitored in a hypertrophic reservoir (Lake Wangsong) before and after the reduction of phosphorus loading from a point source (a sewage treatment plant) by the installation of a chemical phosphorus-removal process.
\end{abstract}

Results: Before phosphorus removal, Lake Wangsong was classified as hypertrophic with a median phosphorus concentration of $0.232 \mathrm{mg} \mathrm{L}^{-1}$ and a median chlorophyll-a concentration of $112 \mathrm{mg} \mathrm{L}^{-1}$. The dominant phytoplankton were filamentous cyanobacteria for the most of the ice-free season. Following the installation of the advanced treatment process, phosphorus concentrations were reduced to $81 \mathrm{mg} \mathrm{L}^{-1}$, and the N/P atomic ratio increased from 42 to 102. Chlorophyll-a concentrations decreased to $42 \mathrm{\mu g} \mathrm{L}^{-1}$, and the duration of cyanobacterial dominance was confined to the summer season. Cyanobacteria in spring and autumn were replaced by diatoms and cryptomonads. Filamentous cyanobacteria in summer were replaced by colony-forming unicellular Microcystis spp. It was remarkable that zooplankton biomass increased despite the decrease in phytoplankton biomass, and especially cladoceran zooplankton which increased drastically. These responses to the reduction of point source $\mathrm{P}$ loading to Lake Wangsong imply that reducing the point source P loading can have a big impact even when nonpoint sources account for a large fraction of the total annual phosphorus loading.

Conclusions: Our results also show that the phytoplankton community can shift to decreased cyanobacterial dominance and the zooplankton community can shift to higher cladoceran dominance, even when phosphorus concentrations remain within the typical range for eutrophic lakes following the reduction of phosphorus loading.

Keywords: Eutrophication, Phosphorus removal, Phytoplankton, Point source, Zooplankton

\footnotetext{
* Correspondence: bkim@kangwon.ac.kr

${ }^{1}$ Department of Environmental Science, Kangwon National University,

Chuncheon 24341, South Korea

Full list of author information is available at the end of the article
} 


\section{Background}

Eutrophication is the most common water quality problem in lakes and reservoirs (Azevedo et al. 2015; Reed-Andersen et al. 2000), and phosphorus is the major limiting factor of eutrophication (Schindler 1977; Withers and Jarvie 2008). Phosphorus (P) comes mostly from animal excretion and fertilizer, and the sources are classified as point sources or nonpoint sources (Kundu et al. 2015; Carson et al. 2015). In most rural watersheds, nonpoint $\mathrm{P}$ sources such as agricultural fields and forest are the major sources of the total P load. However, if there is significant urban development within the watershed, sewage discharge can contribute a considerable portion of $\mathrm{P}$ loading (Neal et al. 2000; Jarvie et al. 2006). In watersheds consisting of complex terrain with urban and rural land use, $\mathrm{P}$ loading from agricultural fields is usually larger than the $\mathrm{P}$ loading from sewage. However, the export of $\mathrm{P}$ from nonpoint sources is exported mostly on rainy days in the form of storm runoffs (Li et al. 2015). On the contrary, P loading from point sources have uniform flow rates, and on dry days, their contribution can be larger than those of nonpoint sources.

Hydraulic residence time can be another factor that determines the relative importance of storm runoff in lakes and reservoirs (Dillon 1975; Brett and Benjamin 2008). Shock loading from agricultural nonpoint sources can be very large during a storm event, but a large portion of the $\mathrm{P}$ loading can be flushed out of reservoirs with short residence times. Therefore, there are still many important questions remaining concerning the relative importance of point and nonpoint $\mathrm{P}$ loading. There might be some skepticism regarding the effectiveness of reductions in point source $P$ loading which result in only a partial reduction of the annual $\mathrm{P}$ loading (Mainstone and Parr 2002).

Point sources of $\mathrm{P}$ include raw sewage discharge or effluent from sewage treatment plants which do not have chemical phosphorus-removal processes. The sewage treatment process can be divided into three phases: primary treatment, secondary treatment, and tertiary treatment (or advanced treatment). Commonly, in developed countries, sewage is treated using secondary treatment processes, biological treatment processes designed mainly for biological oxygen demand (BOD) removal (Cullen and Forsberg 1988). Because P concentrations in the effluent from secondary treatment $\left(1-2 \mathrm{mg} \mathrm{P} \mathrm{L}^{-1}\right)$ is 30-60 times higher than the typical criterion for eutrophication (typically $0.03 \mathrm{mg} \mathrm{P} \mathrm{L}^{-1}$ ), advanced $\mathrm{P}$ treatment using chemical precipitation has been incorporated in some sewage treatment plants in Korea that discharge effluent into sensitive surface waters. The legal standards for $\mathrm{P}$ concentrations in effluent from treatment plants are between 0.2 and $0.5 \mathrm{mg} \mathrm{P} \mathrm{L}^{-1}$, still substantially higher than the criterion for eutrophication.
In hypertrophic lakes where $\mathrm{P}$ concentrations are too high even after a reduction of point source $\mathrm{P}$ loading, the in-lake $\mathrm{P}$ concentrations may still remain in the typical range for eutrophic lakes (Schindler 2006). As part of efforts to provide a scientific basis for decisionmaking and developing strategies for water quality management, detailed information on the consequences of a reduction in $\mathrm{P}$ loading and especially the effects on water quality and the phytoplankton and zooplankton communities is required.

Lake Wangsong is a hypertrophic reservoir located in a watershed with mixed urban and rural land use (Table 1). The lake has been hypertrophic since a sewage treatment plant (STP) was constructed on the shore of the lake. Because the STP effluent contained high $\mathrm{P}$ concentrations, the discharge from the STP was identified as the major cause of eutrophication, and the advanced treatment process was added to the plant to reduce $\mathrm{P}$ concentration in the STP effluent. In this study, water quality and the phytoplankton and zooplankton communities were surveyed before and after the installation of the advanced sewage treatment process in order to examine the effectiveness of the $\mathrm{P}$ removal process for the water quality improvement in a hypertrophic lake. We also examined the effect of the reduction in $\mathrm{P}$ loading on the phytoplankton and zooplankton communities in this lake.

\section{Methods}

Lake Wangsong was constructed on the Hwangkujichon Stream (Uiwang city) for providing irrigation water for agriculture (Fig. 1). Rapid urbanization within the watershed resulted in an increase in sewage discharge, thus discharging a large amount of P into the lake. In 1999, the STP was constructed at the shore of the lake, and the advanced treatment process using chemical precipitation was added in August of 2007 to reduce P concentrations in the effluent.

Table 1 Morphological characteristics of Lake Wangsong

\begin{tabular}{|c|c|c|}
\hline \multicolumn{2}{|c|}{ Watershed area $\left(\mathrm{km}^{2}\right)$} & 15.5 \\
\hline \multicolumn{2}{|c|}{ Mean depth (m) } & 2.5 \\
\hline \multicolumn{2}{|c|}{ Total water storage capacity $\left(10^{3} \mathrm{~m}^{3}\right)$} & 2079 \\
\hline \multicolumn{2}{|c|}{ Maximum surface area $\left(\mathrm{km}^{2}\right)$} & 0.86 \\
\hline \multicolumn{2}{|c|}{ Hydraulic residence time (days) } & 49 \\
\hline \multirow[t]{5}{*}{ Land use (ha) } & Agriculture (upland field) & $290(18.6 \%)$ \\
\hline & Agriculture (paddy field) & $320(20.6 \%)$ \\
\hline & Forest & $685(44.1 \%)$ \\
\hline & Residential area & $182(11.7 \%)$ \\
\hline & Others & $78(5.0 \%)$ \\
\hline \multicolumn{2}{|c|}{ Total population } & 27,994 \\
\hline \multicolumn{2}{|c|}{ Population density (pop. km²) } & 1806 \\
\hline
\end{tabular}




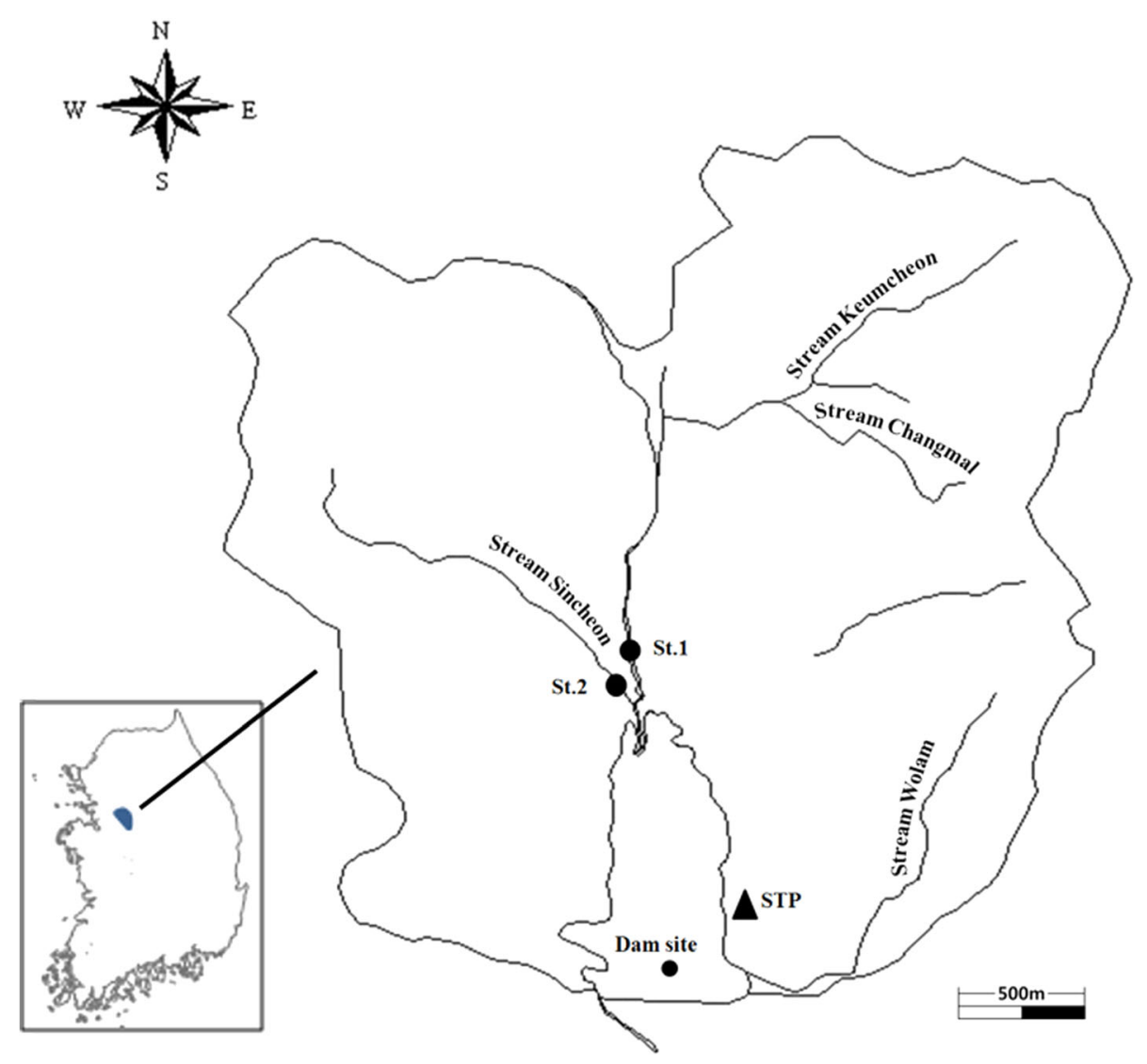

Fig. 1 Sampling sites in Lake Wangsong

The phytoplankton and zooplankton communities and water quality were surveyed before the advanced treatment operation (2003 and 2004) and after the advanced treatment (2008 and 2009). Water samples were collected from the center of the lake at 0,2 , and $5-\mathrm{m}$ depths. Two main inflowing streams were surveyed in order to assess $\mathrm{P}$ loading from the watershed in the dry season. In this study, water quality measurements of the STP effluent were measured and, also, the data from the STP management office were employed together for calculating the P loading from the STP effluent.

Water samples were collected using an inflatable boat and a horizontal Van Dorn water sampler. The water samples were transported in a cooler and stored in a refrigerator until analysis. Dissolved oxygen was measured in situ with a DO meter (YSI, USA). All water quality measurements were conducted according to standard methods (American Public Health Association 2005) except chemical oxygen demand (COD). Total phosphorus (TP) concentration was measured using the ascorbic acid method following persulfate digestion. Chlorophyll-a concentration was measured by the trichromatic spectrophotometric method. Total nitrogen (TN) was measured by the cadmium reduction method following persulfate digestion. Suspended solids (SS) was measured gravimetrically after filtration by GF/F filter. Biological oxygen demand (BOD) was measured by using a DO meter. COD measurements used the permanganate method, the official standard method in Korea (MOE 2009).

Water quality data collected at the surface of the lake by the Gyeonggido local province was also employed in addition to the data collected by this study in order to increase statistical significance in the comparison of water quality before and after the advanced treatment. Stream discharge of inflowing streams was measured using a magnetic flow velocity meter and the current cross-section method. P loading from nonpoint sources in the watershed was estimated by multiplying the unit export coefficients of phosphorus by the area of each land use type as suggested by the Korean Ministry of the Environment (MOE 2014).

Phytoplankton samples were collected in 500-mL polyethylene bottles at $0.5-\mathrm{m}$ depth and preserved with 
Lugol's solution. Cell densities were measured using a Sedgewick-Rafter counting chamber and an X300 microscope (Olympus BX50). Zooplankton samples were collected with a plankton net (63- $\mu \mathrm{m}$ mesh) using a slow vertical tow from the bottom (typically 5-6-m depth) to the surface of the lake. Zooplankton samples were preserved with $4 \%$ sucrose formalin (Steedman 1976). The volume of water filtered by a zooplankton net was calculated by multiplying the aperture area of the net by the towing distance, assuming there is no significant loss of filtering efficiency through a 5-m towing.

\section{Results}

\section{Nutrient loading and water quality}

Water quality parameters in the two main inflowing streams and the STP effluent are shown in Table 2. In general, the nutrient status in the inflowing streams indicates eutrophic conditions. The median TP concentration was 0.131 and $0.190 \mathrm{mg} \mathrm{P} \mathrm{L} \mathrm{L}^{-1}$ at St.1 and St.2, respectively. TP concentrations in the STP effluent were much higher than either St.1 or St.2 in 2003-2007 (median TP $0.633 \mathrm{mg} \mathrm{P} \mathrm{L}^{-1}$ ). Following the phosphorus removal (in 2008), TP concentrations in the effluent were lower (median $0.310 \mathrm{mg} \mathrm{P} \mathrm{L}^{-1}$ ).

The annual average daily $\mathrm{P}$ loading from nonpoint sources in the Lake Wangsong watershed was $7.5 \mathrm{~kg} \mathrm{P} \mathrm{day}^{-1}$, which was higher than the P loading from the major point source (STP effluent), $3.7 \mathrm{~kg} \mathrm{P}$ day $^{-1}$ (Gyeonggi Research Institute 2011). But most of the annual P loading from agricultural nonpoint sources is concentrated in a few rain events during the summer monsoon season in Korea, and only limited amounts of $\mathrm{P}$ export occur on dry days. When the daily P loading was measured in dry seasons, the P discharge from the STP effluent accounted for a larger portion (56 and $60 \%$ ) than the $\mathrm{P}$ loading from the two main inflowing streams (Table 3).

In August of 2007, the advanced P removal treatment started operation. With the reduction of $\mathrm{P}$ loading, TP
Table 3 Comparison of daily phosphorus loading on dry days from the watershed (St.1 and St.2) and sewage treatment plant effluent (STP)

\begin{tabular}{lllll}
\hline Date & & St.1 & St.2 & STP \\
\hline 25 Sep. 2008 & $\begin{array}{l}\text { Flow rate } \\
\left(\mathrm{m}^{3} \text { day }^{-1}\right)\end{array}$ & 15,314 & 7733 & 11,584 \\
& $\begin{array}{l}\text { P loading } \\
\left(\mathrm{kg} \mathrm{day}^{-1}\right)\end{array}$ & $\begin{array}{l}1.75 \\
(26.3 \%)\end{array}$ & $\begin{array}{l}0.91 \\
(13.7 \%)\end{array}$ & 3.98 \\
& $(60.0 \%)$ \\
31 Oct. 2008 & Flow rate & 10,152 & 6229 & 11,910 \\
& $\left(\mathrm{~m}^{3}\right.$ day $\left.^{-1}\right)$ & & & \\
& P loading & 1.71 & 0.9 & 3.37 \\
& $\left(\mathrm{~kg} \mathrm{day}^{-1}\right)$ & $(28.7 \%)$ & $(15.1 \%)$ & $(56.2 \%)$ \\
\hline
\end{tabular}

concentrations in the surface have decreased from 0.232 to $0.081 \mathrm{mg} \mathrm{P} \mathrm{L}^{-1}$ (median), a reduction of $65 \%$ (Table 2). But even after the advanced treatment, TP concentrations in the STP effluent were ten times higher than the typical criterion for eutrophic conditions $\left(0.03 \mathrm{mg} \mathrm{P} \mathrm{L}^{-1}\right)$. Consequently, TP in Lake Wangsong also exceeded the threshold of eutrophication by a factor of 2.5 .

Because the advanced treatment was focused on the chemical removal of $\mathrm{P}$, which has a lower removal efficiency than nitrogen, TN concentrations did not decrease as much as TP concentrations. With the higher removal efficiency of $\mathrm{P}$ than $\mathrm{N}$, the atomic $\mathrm{N} / \mathrm{P}$ ratio in the lake increased from 68 to 154 following the start of the advanced treatment. Thus, the atomic N/P was much higher than the Redfield ratio (16) (Redfield 1958) implying P limitation of algal growth in Lake Wangsong.

Suspended solids (SS) in the lake did not change after the advanced treatment. The median SS was $19 \mathrm{mg} \mathrm{L}^{-1}$, suggesting that the seston is composed of mostly inorganic particles, possibly arising from the bottom sediment in this shallow reservoir. Assuming that the chlorophyll-a content of algal cells is commonly $1 \%$ of dry weight and the median chlorophylla concentration of $42.2 \mathrm{ug} \mathrm{L} \mathrm{m}{ }^{-1}$ in Lake Wangsong, algal cells would account for an algal biomass of

Table 2 Water quality of inflowing streams and lake surface (median, $\mathrm{mg} \mathrm{L}^{-1}$; Chl.a, ug L ${ }^{-1}$, (25th-75th percentile))

\begin{tabular}{|c|c|c|c|c|c|c|c|c|c|c|}
\hline & BOD & COD & SS & $\mathrm{TN}$ & TP & Chl.a & $\mathrm{BOD} / \mathrm{COD}$ & N/P (atomic) & Chl.a/TP & Number \\
\hline $\begin{array}{l}\text { Inflow St.1 } \\
\text { (2008-2009) }\end{array}$ & $\begin{array}{l}4.6 \\
(3.1-5.0)\end{array}$ & $\begin{array}{l}6.4 \\
(5.9-6.4)\end{array}$ & $\begin{array}{l}45.7 \\
(32.0-71.5)\end{array}$ & $\begin{array}{l}3.73 \\
(3.71-4.89)\end{array}$ & $\begin{array}{l}0.190 \\
(0.124-0.244)\end{array}$ & & $\begin{array}{l}0.16 \\
(0.09-0.23)\end{array}$ & $\begin{array}{l}51 \\
(38-54)\end{array}$ & & 10 \\
\hline $\begin{array}{l}\text { Inflow St.2 } \\
\text { (2008-2009) }\end{array}$ & $\begin{array}{l}2.7 \\
(1.3-5.0)\end{array}$ & $\begin{array}{l}6.4 \\
(5.0-8.1)\end{array}$ & $\begin{array}{l}11.9 \\
(5.7-44.1)\end{array}$ & $\begin{array}{l}3.76 \\
(3.30-4.37)\end{array}$ & $\begin{array}{l}0.131 \\
(0.113-0.222)\end{array}$ & & $\begin{array}{l}0.42 \\
(0.23-0.79)\end{array}$ & $\begin{array}{l}48 \\
(38-68)\end{array}$ & & 10 \\
\hline $\begin{array}{l}\text { STP effluent } \\
\text { (2003-2007) }\end{array}$ & $\begin{array}{l}10.4 \\
(8.3-12.7)\end{array}$ & $\begin{array}{l}14.9 \\
(12.3-17.7)\end{array}$ & $\begin{array}{l}12.5 \\
(7.1-23.3)\end{array}$ & $\begin{array}{l}7.9 \\
(5.9-13.6)\end{array}$ & $\begin{array}{l}0.633 \\
(0.270-1.299)\end{array}$ & & $\begin{array}{l}0.65 \\
(0.50-0.77)\end{array}$ & $\begin{array}{l}28 \\
(21-44)\end{array}$ & & 24 \\
\hline $\begin{array}{l}\text { STP effluent } \\
\text { (2008-2009) }\end{array}$ & $\begin{array}{l}1.6 \\
(1.0-2.2)\end{array}$ & $\begin{array}{l}6.8 \\
(6.0-7.8)\end{array}$ & $\begin{array}{l}1.9 \\
(1.4-3.6)\end{array}$ & $\begin{array}{l}10.6 \\
(8.9-12.5)\end{array}$ & $\begin{array}{l}0.310 \\
(0.185-0.355)\end{array}$ & & $\begin{array}{l}0.25 \\
(0.15-0.32)\end{array}$ & $\begin{array}{l}78 \\
(61-88)\end{array}$ & & 29 \\
\hline $\begin{array}{l}\text { Lake surface } \\
\text { (May 1999-Jun. 2007) }\end{array}$ & $\begin{array}{l}11.4 \\
(8.7-13.7)\end{array}$ & $\begin{array}{l}15.8 \\
(13.2-18.4)\end{array}$ & $\begin{array}{l}20.4 \\
(16.0-30.7)\end{array}$ & $\begin{array}{l}4.75 \\
(3.47-5.87)\end{array}$ & $\begin{array}{l}0.232 \\
(0.181-0.284)\end{array}$ & $\begin{array}{l}112.4 \\
(53.9-163.7)\end{array}$ & $\begin{array}{l}0.70 \\
(0.51-0.87)\end{array}$ & $\begin{array}{l}42 \\
(27-70)\end{array}$ & $\begin{array}{l}0.54 \\
(0.22-0.84)\end{array}$ & 42 \\
\hline $\begin{array}{l}\text { Lake surface } \\
\text { (Aug. 2007-Nov. 2009) }\end{array}$ & $\begin{array}{l}5.2 \\
(4.1-7.1)\end{array}$ & $\begin{array}{l}10.2 \\
(8.7-11.3)\end{array}$ & $\begin{array}{l}19.1 \\
(13.9-30.8)\end{array}$ & $\begin{array}{l}3.56 \\
(2.31-4.93)\end{array}$ & $\begin{array}{l}0.081 \\
(0.054-0.137)\end{array}$ & $\begin{array}{l}42.2 \\
(24.9-110.8)\end{array}$ & $\begin{array}{l}0.59 \\
(0.47-0.69)\end{array}$ & $\begin{array}{l}102 \\
(68-154)\end{array}$ & $\begin{array}{l}0.61 \\
(0.28-1.15)\end{array}$ & 20 \\
\hline
\end{tabular}


approximately $4 \mathrm{mg} \mathrm{L}^{-1}$, much lower than the SS. Therefore, inorganic particles would account for $15 \mathrm{mg} \mathrm{L}^{-1}$ in the SS. In Lake Wangsong, resuspension of sediment is likely common on windy days. The decrease in BOD following the reduction in $\mathrm{P}$ loading affected the hypolimnetic DO concentrations, a common criterion for eutrophication (Horne and Goldman 1994). Anoxic conditions in the hypolimnion clearly developed below 4-m depth in September 2003 and May to August 2004, whereas the hypolimnion was oxic in 2009.

\section{Phytoplankton and zooplankton}

With decreased in-lake TP, chlorophyll-a concentrations decreased drastically from a median of $112.4 \mathrm{mg} \mathrm{m}^{-3}$ before the advanced treatment to $42.2 \mathrm{mg} \mathrm{m}^{-3}$ after the advanced treatment; the decrease in chlorophyll-a was $62 \%$, similar to the decrease in TP (65\%, Table 2). The maximum cell density for cyanobacteria also decreased drastically from $25 \times 10^{5}$ cells $\mathrm{mL}^{-1}$ to $9 \times 10^{5}$ cells $\mathrm{mL}^{-1}$ (Table 4). The phytoplankton species composition changed together with a decrease in algal standing crop. In 2003 and 2004, cyanobacteria were the dominant phytoplankton species during most of the ice- free season from April to December. It was remarkable that cyanobacteria were dominant even in winter. By contrast, after the advanced treatment, cyanobacteria were dominant in only 4 samples out of 12 monthly samples (Table 4). In the summer months, cyanobacteria were still dominant, but in spring and autumn, cryptomonads replaced cyanobacteria. In the winter samples, diatoms were the dominant phytoplankton. In a statistical comparison, the density of diatoms and cyanobacteria showed significant difference between before and after the advanced treatment $(p<0.05)$.

With the change in phytoplankton species composition, the dominant zooplankton also changed (Table 5). The most remarkable change was that large-sized cladoceran zooplankton (Daphnia galeata) reached the maximum density in spring and autumn when cyanobacteria were not dominant. Before the advanced treatment started, the maximum cladoceran density was 250 ind. L

${ }^{-1}$ in July and August, whereas in April 2008, the density of cladocerans was 1242 ind. $\mathrm{L}^{-1}$. In the statistical analysis, the density and dominance of cladocerans between before and after the advanced treatment showed significant differences.

Table 4 Cell densities of three major phytoplankton taxa and dominant species before and after advanced sewage treatment

\begin{tabular}{|c|c|c|c|c|c|c|c|}
\hline \multirow[t]{2}{*}{ Year } & \multirow[t]{2}{*}{ Month } & \multicolumn{5}{|c|}{ Cell density (cells $\mathrm{mL}^{-1}$ ) } & \multirow{2}{*}{$\begin{array}{l}\text { Dominant species } \\
\text { (by biomass, } \mu g \mathrm{CL}^{-1} \text { ) }\end{array}$} \\
\hline & & Bacillariophyceae & Cyanophyceae & Chlorophyceae & Others & Total & \\
\hline \multirow[t]{3}{*}{2003} & Sep. & 6408 & 497,304 & 534 & 971 & 505,217 & Oscillatoria sp. \\
\hline & Nov. & 4269 & 213,537 & 5817 & 123 & 223,746 & Microcystis sp. \\
\hline & Dec. & 115 & 59,486 & 3326 & 1840 & 64,767 & Oscillatoria sp. \\
\hline \multirow[t]{6}{*}{2004} & Mar. & 381 & 757 & 545 & 25 & 1708 & Closterium sp. \\
\hline & Apr. & 185 & 130,010 & 122,333 & 3933 & 256,461 & Anabaena sp. \\
\hline & May & 43 & $1,474,200$ & 54,871 & 1207 & $1,530,321$ & Lyngbya sp. \\
\hline & Jun. & 58 & $2,515,477$ & 1234 & 13,247 & $2,530,016$ & Microcystis sp. \\
\hline & Jul. & 3385 & 508,721 & 1362 & 34 & 513,502 & Lyngbya sp. \\
\hline & Aug. & 299 & $1,378,199$ & 59 & 595 & $1,379,152$ & Microcystis sp. \\
\hline \multicolumn{8}{|c|}{ Advanced treatment start } \\
\hline \multirow[t]{2}{*}{2007} & Nov. & 36 & 7088 & 89 & 1148 & 8361 & Cryptomonas ovata \\
\hline & Dec.. & 2196 & 673 & 414 & 61 & 3344 & Stephanodiscus hantzschii \\
\hline \multirow[t]{7}{*}{2008} & Apr. & & & 1055 & 1570 & 2625 & Cryptomonas ovata \\
\hline & May & 2 & 796 & 39,744 & 389 & 40,931 & Pediastrum duplex \\
\hline & Jun. & 2 & 897,039 & 276 & 22 & 897,339 & Microcystis aeruginosa \\
\hline & Jul. & 230 & 33,155 & 469 & 533 & 34,386 & Microcystis aeruginosa \\
\hline & Aug. & 20 & 160,053 & 111 & 2215 & 162,399 & Microcystis wesenbergii \\
\hline & Sep. & 210 & 30,197 & 2806 & 393 & 33,606 & Oscillatoria sancta \\
\hline & Dec. & 5581 & 13 & 1148 & 47 & 6789 & Stephanodiscus hantzschii \\
\hline \multirow[t]{3}{*}{2009} & Mar. & 24 & & 190 & 315 & 528 & Cryptomonas sp. \\
\hline & May & 8 & & 3524 & 1168 & 4701 & Cryptomonas sp. \\
\hline & Sep. & 12 & 2349 & 24 & 133 & 2518 & Cryptomonas sp. \\
\hline
\end{tabular}


Table 5 Standing crop and dominant zooplankton species

\begin{tabular}{|c|c|c|c|c|c|c|}
\hline \multirow[t]{2}{*}{ Year } & \multirow[t]{2}{*}{ Month } & \multicolumn{4}{|c|}{ Standing crop (ind. $\mathrm{L}^{-1}$ ) } & \multirow[t]{2}{*}{ Dominant species } \\
\hline & & Cladocera & Copepoda & Rotifera & Total & \\
\hline \multirow[t]{3}{*}{2003} & Sep. & 57 & 19 & 13 & 89 & Bosmina longirostris \\
\hline & Nov. & 2 & 18 & 21 & 41 & Cyclops vicinus \\
\hline & Dec. & 21 & 14 & 122 & 157 & Asplanchna priodonta \\
\hline \multirow[t]{6}{*}{2004} & Mar. & 1 & 13 & 85 & 98 & Cyclops vicinus \\
\hline & Apr. & 44 & 29 & 2731 & 2804 & Cyclops vicinus \\
\hline & May & 0 & 1 & 10 & 11 & Nauplius \\
\hline & Jun. & 48 & 298 & 1805 & 2151 & Thermocyclops taihokuensis \\
\hline & Jul. & 254 & 368 & 1555 & 2177 & Thermocyclops taihokuensis \\
\hline & Aug. & 243 & 271 & 989 & 1504 & Nauplius \\
\hline \multicolumn{7}{|c|}{ Advanced treatment start } \\
\hline \multirow[t]{2}{*}{2007} & Nov. & 5 & 18 & 20 & 43 & Bosmina longirostris \\
\hline & Dec. & 12 & 58 & 12 & 88 & Cyclops vicinus \\
\hline \multirow[t]{8}{*}{2008} & Apr. & 1242 & 1089 & 1531 & 3862 & Daphnia galeata \\
\hline & May & 550 & 342 & 626 & 1518 & Cyclops vicinus \\
\hline & Jun. & 49 & 162 & 54 & 266 & Daphnia galeata \\
\hline & Jul. & 77 & 212 & 1384 & 1674 & Copepodite \\
\hline & Aug. & 22 & 235 & 1561 & 1818 & Brachionus forficula \\
\hline & Sep. & 97 & 306 & 2704 & 3105 & Keratella cochlearis \\
\hline & Oct. & 510 & 1729 & 1758 & 3997 & Daphnia galeata \\
\hline & Dec. & 217 & 466 & 3616 & 4299 & Cyclops vicinus \\
\hline \multirow[t]{3}{*}{2009} & Mar. & 21 & 120 & 154 & 295 & Cyclops vicinus \\
\hline & May & 0 & 0 & 2275 & 2275 & Daphnia galeata \\
\hline & Sep. & 9 & 82 & 493 & 574 & Cyclops vicinus \\
\hline
\end{tabular}

\section{Discussion}

The annual $\mathrm{P}$ loading to lakes from point sources and nonpoint sources is commonly comprised mostly of agricultural nonpoint $\mathrm{P}$ sources in watersheds with mixed land uses. However, in reservoirs with short hydraulic residence time, storm runoff from nonpoint sources is not stored for a long time within the reservoir, especially in the rainy season. Because Korea is located in the summer monsoon region, most of the annual rainfall occurs in summer. Short hydraulic residence times in reservoirs can be a critical factor affecting nutrient concentrations in reservoirs. In the dry season, the relative importance of point sources is larger than nonpoint sources, because nonpoint sources do not export nutrients during periods with minimum stream flow. In this study, the importance of P removal in the STP effluent was obviously manifested in the water quality improvement after the advanced treatment.

Even after the advanced treatment, Lake Wangsong remained eutrophic. TP and chlorophyll-a concentrations were higher than the criteria for eutrophic lakes (Wetzel 2001), mainly because TP in the STP effluent was still much higher than the typical criterion for eutrophication. TP can be reduced to as low as $0.01 \mathrm{mg} \mathrm{P} \mathrm{L}^{-1}$ in STP effluent with advanced chemical treatment. In Korea, the phosphorus standards for STP effluent are in the range of 0.2 to $2.0 \mathrm{mg} \mathrm{L}^{-1}$, still much higher than the eutrophication criterion. Therefore, even if sewage is treated according to the government standard for $\mathrm{P}$ concentration in the effluent, sewage can be a main cause of eutrophication and further reductions in $P$ in STP effluent are strongly needed for the control of eutrophication.

Importantly, we observed that the dominance of cyanobacteria decreased with $\mathrm{P}$ concentrations, even though P concentrations remained in the eutrophic level. The N/P ratio increased due to the $\mathrm{P}$ removal in the STP effluent, which might have provided favorable conditions for algae other than cyanobacteria. A low N/ $\mathrm{P}$ ratio is known to be favorable for cyanobacteria, because $\mathrm{N}$ can be a temporary limiting factor and $\mathrm{N}$-fixing cyanobacteria can take advantage of this $(\mathrm{Gu}$ and Alexander 1993). Temporary nitrogen depletion during algal blooms can be a controlling factor in the competition among phytoplankton species; that is, decreases in $\mathrm{P}$ can provide favorable conditions for other 
algal species and inhibit the dominance of filamentous cyanobacteria (Fulton 1988). Before the start of the advanced treatment, most of the dominant phytoplankton were filamentous cyanobacteria with many species having the potential to carry out $\mathrm{N}$-fixation, whereas filamentous cyanobacteria were dominant only in 1 sample out of 12 monthly samples after the advanced treatment.

The change of the zooplankton community in Lake Wangsong was also obvious. In 2003 and 2004, rotifers were the dominant zooplankton, whereas cladoceran species were the dominant zooplankton in 2008 and 2009 (Table 5). A remarkable result was that zooplankton biomass increased after the advanced treatment even though the phytoplankton biomass decreased. Generally, zooplankton standing crop is associated with the availability of phytoplankton, the so-called bottom-up effect (Sinistro 2009). In addition, copepod and cladoceran densities increased drastically and rotifer density increased slightly. The increase in cladoceran density is usually regarded as a positive change for water quality due to their large filtering capacity which can result in an increase in water clarity (Sommer et al. 2001; Schrage and Downing 2004). Especially, the maximum cladoceran densities in April 2008 and October 2009 may have caused clear water phases due to the high density of D. galeata (Fig. 2). In 2003 and 2004, the

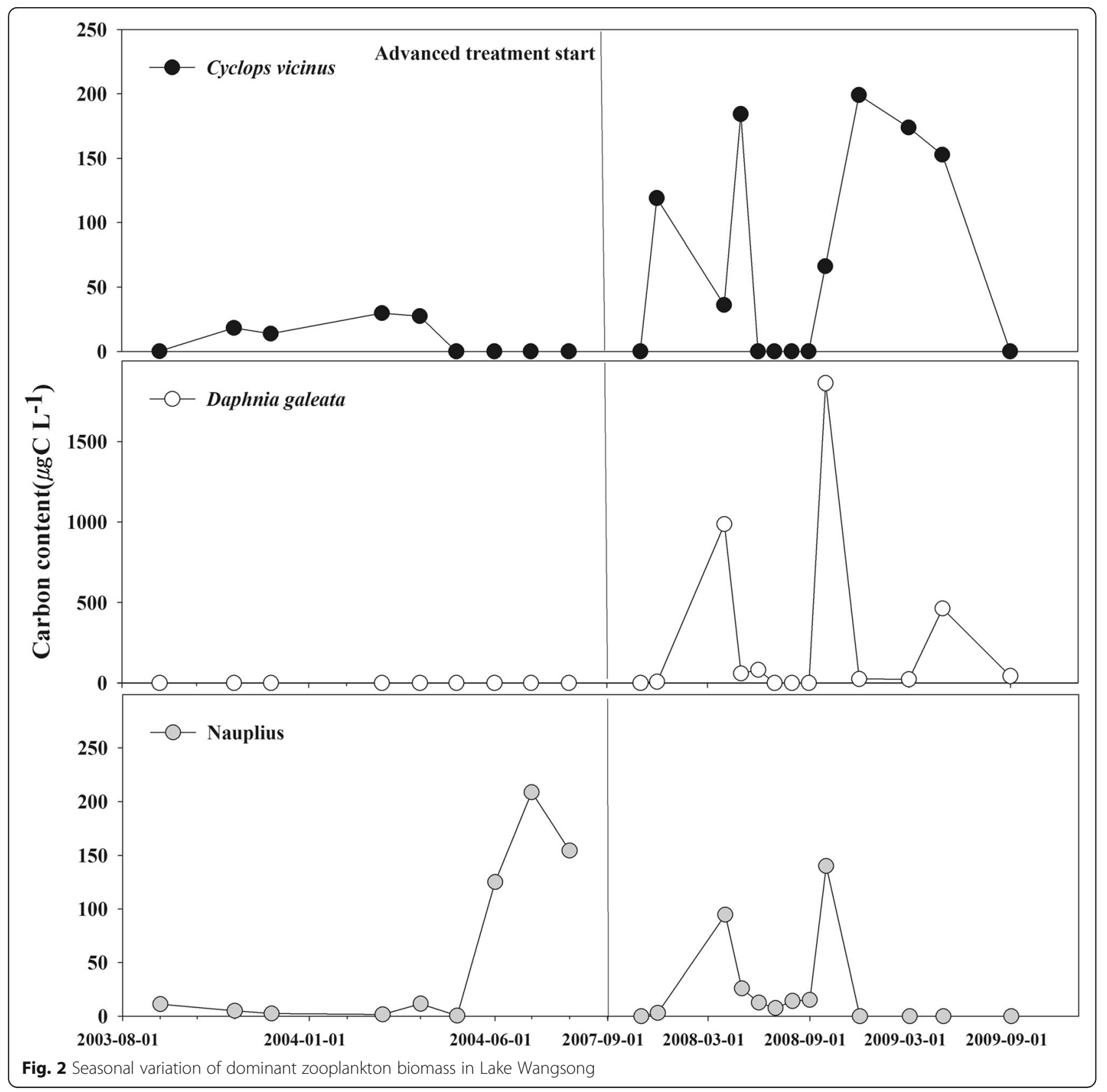


dominant phytoplankton were filamentous cyanobacteria during all seasons, and these species are generally known as inedible prey for zooplankton (Krevš et al. 2010). The change in zooplankton species composition can be explained as the result of change of phytoplankton community from inedible filamentous cyanobacteria to edible diatoms and cryptomonads which were dominant in spring and autumn of 2009 (Bomi et al. 2013).

\section{Conclusions}

The reduction of phosphorus from STP effluent resulted in a significant reduction of in-lake P concentrations in Lake Wangsong, which in turn effected a shift in the phytoplankton community. Even though P concentrations remained within the typical range for eutrophic conditions following the reduction in P loading, all the indicators of water quality and aquatic ecosystem health showed improvements: decreased phytoplankton density, decreased hypoxia in the hypolimnion, a shift from cyanobacteria to diatoms in cold seasons, a shift from filamentous cyanobacteria to colony-forming unicellular cyanobacteria, and increased cladoceran zooplankton populations which can improve water clarity and facilitate the transfer of energy through the grazing food chain. This implies that P removal from STP effluent can be important for improving water quality in hypertrophic reservoirs even if the annual $\mathrm{P}$ loading from nonpoint sources is larger than the P loading from sewage effluent.

\section{Funding}

This study was supported by a 2013 Research Grant from Kangwon National University (no. 120131194). This study was supported by the Center for Aquatic Ecosystem Restoration (CAER) of the Eco-STAR Project from the Ministry of Environment, Republic of Korea (MOE: EW 42-08-10). Support from the Environmental Research Institute at Kangwon National University is also acknowledged.

Availability of data and materials

Please contact the author for data requests.

\section{Authors' contributions}

All authors contributed extensively to the work presented in this paper. BK and $\mathrm{SJ}$ designed the study and wrote the main paper. YL and JL collected the zooplankton data and analyzed the results. SJ, JK, and YC collected and analyzed the phytoplankton data and conducted the data analysis. KK, JO, and AR analyzed the water quality data. All authors discussed the results and implications and commented on the manuscript at all stages.

\section{Competing interests}

The authors declare that they have no competing interests.

\section{Consent for publication}

Not applicable.

\section{Ethics approval and consent to participate}

Not applicable.

\section{Author details}

${ }^{1}$ Department of Environmental Science, Kangwon National University, Chuncheon 24341, South Korea. ${ }^{2}$ Department of Hydrology, University of
Bayreuth, 95447 Bayreuth, Germany. ${ }^{3}$ Department of Environmental Science, Hankuk University of Foreign Studies, Yongin 17053, South Korea.

Received: 11 November 2015 Accepted: 24 June 2016

Published online: 24 October 2016

\section{References}

American Public Health Association, American Water Works Association, Water Environment Federation. (2005). Standard methods for the examination of water and wastewater (21st ed.). Washington, D.C.: American Public Health Association.

Azevedo, L. B., van Zelm, R., Leuven, R. S., Hendriks, A. J., \& Huijbregts, M. A. (2015). Combined ecological risks of nitrogen and phosphorus in European freshwaters. Environmental Pollution, 200, 85-92.

Bomi, C., Misun, S., Jong, I. K., \& Woongghi, S. (2013). Taxonomy and phylogeny of the genus Cryptomonas (Cryptophyceae, Cryptophyta) from Korea. Algae, 28, 307-330.

Brett, M. T., \& Benjamin, M. M. (2008). A review and reassessment of lake phosphorus retention and the nutrient loading concept. Freshwater Biology, 53, 194-211.

Carson, A., Jennings, E., Linnane, S., \& Jordan, S. N. (2015). Clearing the muddy waters: using lake sediment records to inform agricultural management. Journal of Paleolimnology, 53, 1-15.

Cullen, P., \& Forsberg, C. (1988). Experiences with reducing point sources of phosphorus to lakes. Hydrobiologia, 170, 321-336.

Dillon, P. (1975). The phosphorus budget of Cameron Lake, Ontario: the importance of flushing rate to the degree of eutrophy of lakes. Limnology and Oceanography, 20, 28-39.

Fulton, R. S. (1988). Grazing on filamentous algae by herbivorous zooplankton. Freshwater Biology, 20, 263-271.

$\mathrm{Gu}, \mathrm{B} .$, \& Alexander, V. (1993). Estimation of $\mathrm{N}_{2}$ fixation based on differences in the natural abundance of ${ }^{15} \mathrm{~N}$ among freshwater $\mathrm{N}_{2}$-fixing and non- $\mathrm{N}_{2}$-fixing algae. Oecologica, 96, 43-48.

Gyeonggi Research Institute (2011). Water quality management and implementation: alternatives for Wangsong Reservoir.

Horne, A. J., \& Goldman, C. R. (1994). Limnology (2nd ed.). New York: McGraw-Hill Co.

Jarvie, H. P., Neal, C., \& Withers, P. J. (2006). Sewage-effluent phosphorus: a greater risk to river eutrophication than agricultural phosphorus? Science of the Total Environment, 360, 246-253.

Krevš, A., Koreivienè, J., \& Mažeikaitè, S. (2010). Plankton food web structure during cyanobacteria bloom in the highly eutrophic Lake Gineitiškès. Ekologija, 56, 47-54.

Kundu, S., Coumar, M. V., Rajendiran, S., \& Rao, A. S. (2015). Phosphates from detergents and eutrophication of surface water ecosystem in India. Current Science, 108, 1320-1325.

Li, D., Wan, J., Ma, Y., Wang, Y., Huang, M., \& Chen, Y. (2015). Stormwater runoff pollutant loading distributions and their correlation with rainfall and catchment characteristics in a rapidly industrialized city. PloS One. doi:10. 1371/journal.pone.0118776.

Mainstone, C. P., \& Parr, W. (2002). Phosphorus in rivers-ecology and management. Science of the Total Environment, 282, 25-47.

Ministry of Environment. (2009). Standard methods of water sampling and analysis. Korea: Ministry of Environment.

Ministry of Environment. (2014). Total maximum daily load program. Korea: Ministry of Environment.

Neal, C., Jarvie, H. P., Howarth, S. M., Whitehead, P. G., Williams, R. J., Neal, M., Harrow, M., \& Wickham, H. (2000). The water quality of the River Kennet: initial observations on a lowland chalk stream impacted by sewage inputs and phosphorus remediation. Science of the Total Environment, 251, 477-495.

Redfield, A. C. (1958). The biological control of chemical factors in the environment. American Scientist, 46, 205-221.

Reed-Andersen, T., Carpenter, S. R., \& Lathrop, R. C. (2000). Phosphorus flow in a watershed-lake ecosystem. Ecosystems, 3, 561-573.

Schindler, D. W. (1977). Evolution of phosphorus limitation in lakes. Science, $195,260-262$.

Schindler, D. W. (2006). Recent advances in the understanding and management of eutrophication. Limnology and Oceanography, 51, 356-363.

Schrage, L. J., \& Downing, J. A. (2004). Pathways of increased water clarity after fish removal from Ventura Marsh; a shallow, eutrophic wetland. Hydrobiologia, $511,215-231$ 
Sinistro, R. (2009). Top-down and bottom-up regulation of planktonic

communities in a warm temperate wetland. Journal of Plankton Research. doi: 10.1093/plankt/fbp114.

Sommer, U., Sommer, F., Santer, B., Jamieson, C., Boersma, M., Becker, C., \&

Hansen, T. (2001). Complementary impact of copepods and cladocerans on phytoplankton. Ecology Letters, 4, 545-550.

Steedman, H. F. (1976). Zooplankton fixation and preservation. Paris: UNESCO Press. Wetzel, R. G. (2001). Limnology: lake and river ecosystems (3rd ed.). San Diego: Academic. Withers, P., \& Jarvie, H. (2008). Delivery and cycling of phosphorus in rivers: a review. Science of the Total Environment, 400, 379-395.

Submit your next manuscript to BioMed Central and we will help you at every step:

- We accept pre-submission inquiries

- Our selector tool helps you to find the most relevant journal

- We provide round the clock customer support

- Convenient online submission

- Thorough peer review

- Inclusion in PubMed and all major indexing services

- Maximum visibility for your research

Submit your manuscript at www.biomedcentral.com/submit
Biomed Central 